\title{
Obtaining and Evaluating New Hybrids of Papaya Tree
}

\author{
Adriel L. Nascimento ${ }^{1}$, Alan de L. Nascimento ${ }^{2}$, Karina T. H. dos Santos ${ }^{3}$, Renan G. Malikouski ${ }^{3}$, Omar Schmildt ${ }^{3}$, \\ Rodrigo S. Alexandre ${ }^{4}$, Márcio P. Czepak ${ }^{5}$, Laercio F. Cattaneo ${ }^{6}$, Geraldo A. Ferreguetti ${ }^{7}$, \\ José A. T. do Amaral ${ }^{1} \&$ Edilson R. Schmildt ${ }^{3}$ \\ ${ }^{1}$ Federal University of Espírito Santo, Alegre, Brazil \\ ${ }^{2}$ Federal Institute of Education, Science and Technology of Espírito Santo, Montanha Campus, Montanha, Brazil \\ ${ }^{3}$ Laboratory of Plant Breeding, Federal University of Espírito Santo, São Mateus, Brazil \\ ${ }^{4}$ Department of Forest and Wood Science, Federal University of Espírito Santo, Jerônimo Monteiro, Brazil \\ ${ }^{5}$ Department of Agrarian and Biological Sciences, Federal University of Espírito Santo, São Mateus, Brazil \\ ${ }^{6}$ FAESA, Sooretama, Brazil \\ ${ }^{7}$ Caliman Agrícola S.A., Linhares, Brazil
}

Correspondence: Adriel L. Nascimento, Postgraduate Program in Genetics and Breeding, Federal University of Espírito Santo, Alegre, Brazil. E-mail: adriel_aln@outlook.com

Received: March 19, 2018

doi:10.5539/jas.v10n7p146

\author{
Accepted: April 28, $2018 \quad$ Online Published: June 15, 2018 \\ URL: https://doi.org/10.5539/jas.v10n7p146
}

\begin{abstract}
Due to the close genetic base in the papaya crop, the breeding programs seek new alternatives with agronomic characteristics desirable to the producer and fruit that meets the consumer desire. The objective of this work was to evaluate the behavior of new Hybrids in germplasm database maintenance units of the company Caliman Agrícola SA. The experiment was carried out in a randomized block design with 10 new elements $(\mathrm{CP} 3 \times \mathrm{SSAM}$; $\mathrm{CP} 3 \times \mathrm{UENF} /$ Caliman 01; CP3 $\times$ JS 12; CP2 $\times \mathrm{SS32}$; JS $12 \times \mathrm{SSAM}$ ) and one control, UENF/Caliman 01, four replicates and ten plants per plot. Tem hermaphrodite plants per plot were evaluated at eight and 12 months after planting, 16 characteristics focused on plant morphologies and biometry of fruits harvested at the maturation stage II (fruits with up to $25 \%$ of the yellow surface). The productivity of one year of harvest was also evaluated. Among the new hybrids evaluated, it is possible to detect the presence of productive characteristics and fruit quality that were interesting for the market, suggesting that they be evaluated for crop value and use for future launches as commercial hybrids. With interest for future market launch, we highlight CP $3 \times 72 / 12$, CP2 $\times$ SS32, $\mathrm{CP} 3 \times$ Progeny Tainung and CP1 $\times$ Sekati which shows high average productivity.
\end{abstract}

Keywords: Carica papaya L., new cultivars, genetic improvement, genetic variability

\section{Introduction}

The papaya (Carica papaya L.) is one of the most cultivated and consumed fruit trees in the tropical and subtropical regions of the world. In Brazil, it is the seventh in natura fruit most exported, being cultivated in about 30,445 hectares, which are concentrated in the states of Espírito Santo, Bahia, Ceará and Rio Grande do Norte. The country is the world leader in terms of volume of production and area harvested (IBGE, 2015). Over the years, the growth of the agribusiness of papaya in Brazil has been favored by a reasonable technological development.

The culture is supported by a narrow genetic base where national development and success depends on the emergence of new varieties or hybrids that meets market prospects. The hybrid combinations have been carried out by several authors among the group "Solo" and "Formosa" (Marin, Pereira, Amaral Junior, Martelleto, \& Ide, 2006a, 2006b; Ide, Pereira, Viana, \& Pereira, 2009; And Boas, 2015; Luz, Pereira, Barros, \& Ferreguetti, 2015).

The papaya breeding programs are constantly seeking new cultivars that present agronomic characteristics desirable to the producer and fruit characteristics that meet the consumer needs. An alternative and feasible solution to incorporate these characteristics is the knowledge and exploration of the variability existing in active germplasm banks of papaya (Carica papaya L.) (Silva et al., 2017), and resorting to expanding the genetic base through programs by using hybridizations. 
The objective of this work was to promote the evaluation and agronomic characterization of 11 hybrids of papaya, of which 10 were obtained by Caliman Agrícola SA, Linhares, Espírito Santo, in partnership with the Federal University of Espírito Santo, aiming at selecting superior hybrids to be incorporated into the papaya production system in Brazil.

\section{Material and Methods}

The work was carried out at the Santa Teresinha Farm owned by the company Caliman Agrícola SA $\left(19^{\circ} 11^{\prime} 49^{\prime \prime}\right.$ $\mathrm{S}, 40^{\circ} 05^{\prime} 52^{\prime \prime} \mathrm{W}$ and $30 \mathrm{~m}$ altitude), in the County of Linhares, Espírito Santo, between the months from July 2012 to July 2013. The climate of the region is AWi type (tropical humid), with rains in the summer and dry winter.

The experiment was carried out in a randomized block design, with 11 treatments, four replications and 10 plants per plot. The treatments are represented by simple hybrids, being a standard hybrid (UENF/Caliman 01) and 10 new hybrids: $\mathrm{CP} 3 \times \mathrm{SSAM}$; CP3 $\times \mathrm{UENF} /$ Caliman 01; CP3 $\times$ JS 12; CP3 $\times 72 / 12$; CP3 $\times$ Tainung Progeny; CP1 1 Sekati; CP1 $\times$ Tainung Progeny; CP1 $\times$ JS 12; CP2 $\times$ SS32; JS $12 \times$ SSAM. The 10 new hybrids are the result of crosses between the parents belonging to the active germplasm bank of Caliman Agrícola S.A. Among the parents of the mentioned crosses, Progeny Tainung and SSAM belong to the "Solo" group and the others to the "Formosa" group.

The hybrid seeds were obtained from crosses collecting hermaphrodite flowers in the pre-anthesis phase, containing pollen grains that were transferred to female flowers also in the pre-anthesis phase with manual pollination. The previously labeled plants and their flowers were individually protected with waterproof paper bags to avoid contamination with undesirable pollen and crosses were identified by means of plastic labels. The fruits were harvested at 135 to 150 days after pollination at maturation stage 2 (1/4 of mature fruit) and submitted to rest between seven and ten days at room temperature, according to Martins, Silva, Pereira, Araujo, and Posse (2006), and Aroucha, Silva, Oliveira, Pio Viana, and Pereira (2005), sufficient time for immature seeds to reach full germination and vigor.

The Sowing for the production of seedlings was carried out in a nursery with polyolefin screens (50\% shade). Some trays containing 96 tubes with $50 \mathrm{~cm}^{3}$ capacity, filled with Bioplant ${ }^{\circledR}$ substrate added of Basacot mini $3 \mathrm{M}^{\circledR}$ in the proportion of $10 \mathrm{~kg} \mathrm{~m}^{-3}$ of substrate according to Paixão, Schmildt, Matiello, Ferreguetti, and Alexandre (2012) were used, in which two seeds were sown per tube, thinning two weeks after sowing and leaving only the most vigorous seedling.

The seedlings were transplanted to the field after acclimatization in July 2012, about 40 days after sowing, when they were measuring from 12 to $15 \mathrm{~cm}$ in height. Three seedlings per pit were planted to ensure a greater number of hermaphrodite plants. For each treatment, pits with spacing of $3.6 \mathrm{~m}$ between rows and $1.5 \mathrm{~m}$ between plants were prepared in soil of the argisol typical dystrophic argisol type, clay-sandy texture. The sexing was carried out from three months after transplanting, and one seedling was maintained per herd, preferably hermaphrodite. All cultural dealings were carried out following the recommendation of culture (A. N. Costa \& A. F. S. Costa, 2013).

The evaluations were made at eight and 12 months after transplanting, performed in ten hermaphrodite plants per plot. At eight months: plant height $(\mathrm{PH}, \mathrm{cm})$ corresponding to the distance between the soil surface, adjacent to the lap of the plant; height insertion of the first fruit (HIFF, cm)-corresponding to the distance between the soil surface, contiguous to the lap of the plant and the point of insertion of the first fruit; and diameter of the stem (DS, $\mathrm{cm}$ )-evaluated at $20 \mathrm{~cm}$ from the using a pachymeter. The other characteristics were explored considering the evaluations at eight and 12 months: total marketable fruits (TMF)-represents the sum of all fruits with marketing standard at 8 and 12 months per plant; fruit weight $(\mathrm{FW}, \mathrm{g})$-measured on precision scale to three decimal places; fruit length (FL, cm); diameter of the median fruit area $(\mathrm{FD}, \mathrm{cm})$; minor fruit thickness (MFT, $\mathrm{cm})$; greater fruit thickness (GFT, $\mathrm{cm})$; fruit cavity diameter $(\mathrm{FCD}, \mathrm{cm})$-a measurement performed after cross section of the fruit in the equatorial region; (SS-8, ${ }^{\circ}$ Brix) at 8 months and at 12 months (SS-12, ${ }^{\circ}$ Brix), determined on stage II ripening fruits (fruits with up to $25 \%$ of the yellow surface) directly by a table refractometer; internal firmness of the fruit (FIRM-8, $\mathrm{kg} \mathrm{cm}^{-2}$ ) and at 12 months (FIRM-12, $\mathrm{kg} \mathrm{cm}^{-2}$ ), determined by the use of a penetrometer (Instrutherm, medol PTR-100), three equidistant points were evaluated along the thickness of the pulp from the cross section of the fruit using a $7.9 \mathrm{~mm}$ diameter tip.

In a second moment, to calculate the productivity at the time per site, the TMF and FM characteristics were used, obtaining the estimated average productivity of marketable fruits in 12 months (PROD, $\mathrm{t} \mathrm{ha} \mathrm{h}^{-1}$ ). The characteristics related to the fruit FW, FL, FD, MFT, GFT, FCD, SS and FIRM, were represented by ten fruits being one fruit of each plant per plot. 
The data were submitted to analysis of variance $(\mathrm{P}<0.01)$ and later grouping test, Scott-Knott $(1974)$, with $\mathrm{P}<$ 0.05. The data were analyzed using the computational resources of the Genes program (Cruz, 2016).

\section{Results and Discussion}

The results obtained with the analysis of variance showed significant differences $(\mathrm{P}<0.01)$ between the means of the 11 hybrids for all characteristics evaluated (Table 1). The coefficients of experimental variation (CV) were between $5.09 \%$ and $16.03 \%$, being classified as small to medium magnitude according to the papaya classification made by Ferreira et al. (2016).

Table 1. Analysis of variance for the characteristics evaluated with the respective means, coefficient of variation (CV) for the 11 hybrids of Carica papaya $\mathrm{L}$.

\begin{tabular}{llllll}
\hline \multirow{2}{*}{ Characteristic } & \multicolumn{3}{c}{ Square Average } & Total Average & CV $(\%)$ \\
\cline { 2 - 5 } & Block & Hybrids & Residue & 194.82 & 6.03 \\
PH & 427.68 & $1100.54^{* *}$ & 138.17 & 76.63 & 7.58 \\
HIFF & 87.91 & $263.29^{* *}$ & 33.77 & 10.17 & 5.09 \\
SD & 0.10 & $2.01^{* *}$ & 0.27 & 54.72 & 11.43 \\
TMF & 9.02 & $837.10^{* *}$ & 39.11 & 1348.65 & 12.95 \\
FW & 18271.09 & $504933.80^{* *}$ & 30492 & 22.76 & 5.45 \\
FL & 2.38 & $44.86^{* *}$ & 1.54 & 10.98 & 5.64 \\
FD & 0.10 & $2.39^{* *}$ & 0.38 & 2.07 & 6.96 \\
FL/FD & 0.01 & $0.15^{* *}$ & 0.02 & 3.13 & 8.21 \\
GFT & 0.02 & $0.23^{* *}$ & 0.06 & 2.27 & 6.33 \\
MFT & 0.01 & $0.2^{* *}$ & 0.02 & 5.88 & 6.91 \\
FCD & $1.07^{* *}$ & 0.16 & 10.84 & 6.07 \\
SS-8 & 0.32 & $5.17^{* *}$ & 0.43 & 10.78 & 8.09 \\
FIRM-8 & 1.42 & $3.54^{* *}$ & 0.76 & 12.43 & 8.22 \\
SS-12 & 5.04 & $3.90^{* *}$ & 1.04 & 10.81 & 13.26 \\
FIRM-12 & 6.81 & $12.18^{* *}$ & 2.92 & 130.01 & 16.03 \\
PROD & 2.08 & $1525.76^{* *}$ & 434.24 & & \\
\hline
\end{tabular}

Note. ${ }^{* *}$ Significant $\mathrm{F}$ test $(\mathrm{P}<0.01)$, with degree of freedom: Block $=3$; Hybrids $=10$ and Residuals $=30$.

${ }^{1}$ PH (Plant Height, cm); HIFF (Height of insertion of the first fruit, $\mathrm{cm}$ ); SD (stem diameter, cm); TMF (Number of total marketable fruits); FW (Fruit weight, g); FL (Length of fruit, cm); FD (Fruit diameter, cm); FL/FD (Relationship length and fruit diameter); GFT (Greater fruit thickness, cm); MFT (Minor fruit thickness, cm); FCD (Diameter of the fruit cavity, cm); SS-8 (solids soluble at 8 months, ${ }^{\circ}$ Brix); FIRM-8 (Firmness of the fruit at 8 months, $\mathrm{kg} \mathrm{cm}^{-2}$ ); SS-12 (Solids soluble at 12 months, ${ }^{\circ}$ Brix); FIRM-12 (Firmness of the fruit at 12 months, $\mathrm{kg} \mathrm{cm}^{-2}$ ) and PROD (estimated average productivity of marketable fruits in 12 months, in tons per hectare).

The means averages were compared by the Scott-Knott grouping test $(\mathrm{P}<0.05)$ (Table 2). For the PH characteristic three groups were formed, and the group with the lowest mean values was CP3 $\times$ JS $12, \mathrm{CP} 3 \times$ Progeny Tainung and CP1 $\times$ Sekati, ranging from 163.71 to $181.16 \mathrm{~cm}$. The other hybrids presented higher results ranging from 192.89 to $217.44 \mathrm{~cm}$, and the UENF/Caliman 01 control presented a mean of $195.21 \mathrm{~cm}$ being part of the intermediate average group. According to Nakasone and Lamoureux (1982), very tall plants are undesirable because they present very long internodes and, with this, greater space between fruits, lower productivity and production longevity. What is desirable is that the plant presents medium height that favors the harvest, with short internodes, promoting less space between the fruits, reflecting in greater productivity. 
Table 2. Average characteristics evaluated in 11 hybrids of papaya (Carica papaya L.)

\begin{tabular}{|c|c|c|c|c|c|c|}
\hline \multirow{2}{*}{ Hybrids } & \multicolumn{6}{|c|}{ Features $^{1}$} \\
\hline & $\mathrm{PH}$ & HIFF & SD & & TMF & FW \\
\hline $\mathrm{CP} 3 \times \mathrm{SSAM}$ & $214.06 \mathrm{a}^{2}$ & $74.66 \mathrm{~b}$ & $10.41 \mathrm{a}$ & & $74.91 \mathrm{a}$ & $894.52 \mathrm{~d}$ \\
\hline $\mathrm{CP} 3 \times$ UENF/Caliman 01 & $205.87 \mathrm{a}$ & $70.92 \mathrm{~b}$ & $10.37 \mathrm{a}$ & & $57.85 \mathrm{~b}$ & $1049.41 \mathrm{~d}$ \\
\hline $\mathrm{CP} 3 \times \mathrm{JS} 12$ & $163.71 \mathrm{c}$ & $63.52 \mathrm{~b}$ & $8.25 \mathrm{~b}$ & & $32.60 \mathrm{~d}$ & $1921.64 \mathrm{a}$ \\
\hline $\mathrm{CP} 3 \times 72 / 12$ & $192.89 \mathrm{~b}$ & $74.47 \mathrm{~b}$ & $10.09 \mathrm{a}$ & & $66.37 \mathrm{a}$ & $1340.00 \mathrm{c}$ \\
\hline $\mathrm{CP} 3 \times$ Progeny Tainung & $181.16 \mathrm{c}$ & $72.37 \mathrm{~b}$ & $9.89 \mathrm{a}$ & & $66.80 \mathrm{a}$ & $1219.43 \mathrm{c}$ \\
\hline CP1 1 Sekati & $174.76 \mathrm{c}$ & $75.17 \mathrm{~b}$ & $10.02 \mathrm{a}$ & & $43.77 \mathrm{c}$ & $1731.56 \mathrm{a}$ \\
\hline $\mathrm{CP} 1 \times$ Progeny Tainung & $217.44 \mathrm{a}$ & $93.80 \mathrm{a}$ & $10.86 \mathrm{a}$ & & $54.05 \mathrm{~b}$ & $1244.77 \mathrm{c}$ \\
\hline $\mathrm{CP} 1 \times \mathrm{JS} 12$ & $195.32 \mathrm{~b}$ & $87.77 \mathrm{a}$ & $10.15 \mathrm{a}$ & & $28.89 \mathrm{~d}$ & $1865.90 \mathrm{a}$ \\
\hline $\mathrm{CP} 2 \times \mathrm{SS} 32$ & $194.09 \mathrm{~b}$ & $75.33 \mathrm{~b}$ & $10.81 \mathrm{a}$ & & $57.44 \mathrm{~b}$ & $1472.52 \mathrm{~b}$ \\
\hline JS $12 \times$ SSAM & $208.47 \mathrm{a}$ & $78.62 \mathrm{~b}$ & $10.61 \mathrm{a}$ & & $65.17 \mathrm{a}$ & $1045.64 \mathrm{~d}$ \\
\hline \multirow{2}{*}{ UENF/Caliman 01} & $195.21 \mathrm{~b}$ & $76.30 \mathrm{~b}$ & $10.40 \mathrm{a}$ & & $54.03 \mathrm{~b}$ & $1049.75 \mathrm{~d}$ \\
\hline & FL & FD & FL/FD & GFT & MFT & FCD \\
\hline $\mathrm{CP} 3 \times \mathrm{SSAM}$ & $17.88 \mathrm{~d}$ & $9.97 \mathrm{c}$ & $1.79 \mathrm{~b}$ & $3.06 \mathrm{~b}$ & $2.04 \mathrm{~b}$ & $5.57 \mathrm{~b}$ \\
\hline $\mathrm{CP} 3 \times \mathrm{UENF} /$ Caliman 01 & $20.03 \mathrm{c}$ & $10.69 \mathrm{~b}$ & $1.88 \mathrm{~b}$ & $3.04 \mathrm{~b}$ & $2.18 \mathrm{~b}$ & $5.24 \mathrm{~b}$ \\
\hline $\mathrm{CP} 3 \times \mathrm{JS} 12$ & $27.64 \mathrm{a}$ & $12.33 \mathrm{a}$ & $2.25 \mathrm{a}$ & $3.41 \mathrm{a}$ & $2.65 \mathrm{a}$ & $6.76 \mathrm{a}$ \\
\hline $\mathrm{CP} 3 \times 72 / 12$ & $21.57 \mathrm{c}$ & $11.14 \mathrm{a}$ & $1.94 \mathrm{~b}$ & $3.05 \mathrm{~b}$ & $2.20 \mathrm{~b}$ & $6.33 \mathrm{a}$ \\
\hline $\mathrm{CP} 3 \times$ Progeny Tainung & $21.49 \mathrm{c}$ & $10.89 \mathrm{~b}$ & $1.97 \mathrm{~b}$ & $3.02 \mathrm{~b}$ & $2.14 \mathrm{~b}$ & $5.94 \mathrm{a}$ \\
\hline CP1 1 Sekati & $25.21 \mathrm{~b}$ & $11.60 \mathrm{a}$ & $2.17 \mathrm{a}$ & $3.65 \mathrm{a}$ & $2.45 \mathrm{a}$ & $6.14 \mathrm{a}$ \\
\hline CP1 $\times$ Progeny Tainung & $21.5 \mathrm{c}$ & $11.29 \mathrm{a}$ & $1.90 \mathrm{~b}$ & $3.09 \mathrm{~b}$ & $2.08 \mathrm{~b}$ & $6.28 \mathrm{a}$ \\
\hline $\mathrm{CP} 1 \times \mathrm{JS} 12$ & $28.74 \mathrm{a}$ & $11.91 \mathrm{a}$ & $2.42 \mathrm{a}$ & $3.10 \mathrm{~b}$ & $2.54 \mathrm{a}$ & $6.30 \mathrm{a}$ \\
\hline $\mathrm{CP} 2 \times \mathrm{SS} 32$ & $24.58 \mathrm{~b}$ & $10.87 \mathrm{~b}$ & $2.27 \mathrm{a}$ & $3.27 \mathrm{a}$ & $2.52 \mathrm{a}$ & $5.44 \mathrm{~b}$ \\
\hline JS $12 \times$ SSAM & $20.58 \mathrm{c}$ & $10.14 \mathrm{c}$ & $2.03 \mathrm{~b}$ & $2.93 \mathrm{~b}$ & $2.13 \mathrm{~b}$ & $5.30 \mathrm{~b}$ \\
\hline \multirow[t]{2}{*}{ UENF/Caliman 01} & $21.16 \mathrm{c}$ & $10.01 \mathrm{c}$ & $2.11 \mathrm{a}$ & $2.76 \mathrm{~b}$ & $2.07 \mathrm{~b}$ & $5.37 \mathrm{~b}$ \\
\hline & SS-8 & FIRM-8 & SS-12 & & FIRM-12 & PROD \\
\hline $\mathrm{CP} 3 \times \mathrm{SSAM}$ & $12.27 \mathrm{a}$ & $8.49 \mathrm{~b}$ & $12.25 \mathrm{~b}$ & & $8.00 \mathrm{~b}$ & $124.82 \mathrm{~b}$ \\
\hline $\mathrm{CP} 3 \times$ UENF/Caliman 01 & $9.93 \mathrm{c}$ & $10.91 \mathrm{a}$ & $12.50 \mathrm{~b}$ & & $11.97 \mathrm{a}$ & $113.01 \mathrm{~b}$ \\
\hline $\mathrm{CP} 3 \times \mathrm{JS} 12$ & $9.34 \mathrm{c}$ & $12.18 \mathrm{a}$ & $11.50 \mathrm{~b}$ & & $12.50 \mathrm{a}$ & $122.43 \mathrm{~b}$ \\
\hline $\mathrm{CP} 3 \times 72 / 12$ & $11.41 \mathrm{~b}$ & $10.32 \mathrm{a}$ & $11.50 \mathrm{~b}$ & & $11.50 \mathrm{a}$ & $162.74 \mathrm{a}$ \\
\hline CP3 $\times$ Progeny Tainung & $11.05 \mathrm{~b}$ & $10.30 \mathrm{a}$ & $12.50 \mathrm{~b}$ & & $12.50 \mathrm{a}$ & $151.09 \mathrm{a}$ \\
\hline $\mathrm{CP} 1 \times$ Sekati & $9.78 \mathrm{c}$ & $10.37 \mathrm{a}$ & $11.25 \mathrm{~b}$ & & $8.75 \mathrm{~b}$ & $141.92 \mathrm{a}$ \\
\hline $\mathrm{CP} 1 \times$ Progeny Tainung & $10.55 \mathrm{c}$ & $11.12 \mathrm{a}$ & $13.50 \mathrm{a}$ & & $12.50 \mathrm{a}$ & $124.01 \mathrm{~b}$ \\
\hline $\mathrm{CP} 1 \times \mathrm{JS} 12$ & $9.73 \mathrm{c}$ & $11.30 \mathrm{a}$ & $12.25 \mathrm{~b}$ & & $12.32 \mathrm{a}$ & $105.12 \mathrm{~b}$ \\
\hline $\mathrm{CP} 2 \times \mathrm{SS} 32$ & $10.45 \mathrm{c}$ & $10.93 \mathrm{a}$ & $11.75 \mathrm{~b}$ & & $8.75 \mathrm{~b}$ & $152.36 \mathrm{a}$ \\
\hline JS $12 \times$ SSAM & $12.61 \mathrm{a}$ & $11.20 \mathrm{a}$ & $13.50 \mathrm{a}$ & & $9.67 \mathrm{~b}$ & $127.50 \mathrm{~b}$ \\
\hline UENF/Caliman 01 & $12.13 \mathrm{a}$ & $11.44 \mathrm{a}$ & $14.50 \mathrm{a}$ & & $10.50 \mathrm{~b}$ & $105.08 \mathrm{~b}$ \\
\hline
\end{tabular}

Note. ${ }^{1}$ PH (Plant Height, cm); HIFF (Height of insertion of the first fruit, $\mathrm{cm}$ ); SD (stem diameter, cm); TMF (Number of total marketable fruits); FW (Fruit weight, g); FL (Length of fruit, $\mathrm{cm}$ ); FD (Fruit diameter, cm); FL/FD (Relationship length and fruit diameter); GFT (Greater fruit thickness, $\mathrm{cm}$ ); MFT (Minor fruit thickness, $\mathrm{cm}$ ); FCD (Diameter of the fruit cavity, cm); SS-8 (solids soluble at 8 months, ${ }^{\circ}$ Brix); FIRM-8 (Firmness of the fruit at 8 months, $\mathrm{kg} \mathrm{cm}^{-2}$ ); SS-12 (Solids soluble at 12 months, ${ }^{\circ}$ Brix); FIRM-12 (Firmness of the fruit at 12 months, $\mathrm{kg} \mathrm{cm}^{-2}$ ) and PROD (estimated average productivity of marketable fruits in 12 months, in tons per hectare).

${ }^{2}$ Average followed by the same letter in the column does not differ from one another by Scott-Knott's grouping test $(\mathrm{P}<0.05)$.

As for the HIFF characteristic the averages ranged from $63.52(\mathrm{CP} 3 \times \mathrm{JS} 12)$ to $93.80 \mathrm{~cm}(\mathrm{CP} 1 \times$ Progeny Tainung) constituting two groups by the Scott-Knott group. It is preferable to select cultivars that initiate the insertion of the first flower at a lower height (Alonso, Tornet, Ramos, Farres, Castro, \& Rodriguez, 2008). The 
low insertion height of the first fruit is associated with precocity (Dias, Oliveira, \& Dantas, 2011) and allows a greater longevity of the harvest, resulting in higher production per plant, allowing the exploration of more advanced cycles of papaya (Dantas \& Lima, 2001).

The evaluated SD composed two groups, the highest average values represented by more than $90 \%$ of the hybrids ranged from 9.89 to $10.86 \mathrm{~cm}$, representing group 'a' and the lowest average of $8.25 \mathrm{~cm}$ (CR3 $\times$ JS 12 ) representing group ' $b$ ' (Table 2). According to Rodriguez and Rosell (2005), this characteristic indicates a relation regarding vigor ( $>$ diameter $>$ vigor), being an important relation to be considered in the selection of hybrids.

The average values of $\mathrm{SD}=10.17 \mathrm{~cm}$ agree with the range of means found by Rodolfo Junior et al. (2007), where they found values of $10.95 \mathrm{~cm}$ ("Formosa") and $8.68 \mathrm{~cm}$ ("Solo"). Fraife Filho, Dantas, Leite, and Oliveira (2001), and Silva et al. (2007) indicate that the selection of plants with greater diameter of the stem can result in more productive plants, due to the high genetic correlation between these characteristics.

The High phenotypic variation for morphological and agronomic characteristics in papaya, such as fruit size and shape, pulp flavor and sweetness, plant height and number of fruits per plant, has been reported in the literature and can be exploited (Oliveira, Lima, Lucena, Motta, \& Dantas, 2010; Dias et al., 2011).

The TMF per hybrid varied from 28.89 to 74.91 , allowing the formation of four groups. The UENF/Caliman 01 $(\mathrm{TMF}=54.03)$ was inserted into the ' $\mathrm{b}$ ' group of intermediate means. In the ' $\mathrm{a}$ ' group for the TMF characteristic, the highest mean values were CP3 $\times$ SSAM (74.91), CP3 $\times 72 / 12$ (66.37), CP3 $\times$ Progeny Tainung (66.80) and $\operatorname{JS} 12 \times \operatorname{SSAM}(65.17)$.

The FW presented a variation of $894.52 \mathrm{~g}(\mathrm{CP} 3 \times \mathrm{SSAM})$ at $1921.64 \mathrm{~g}(\mathrm{CP} 3 \times \mathrm{JS} 12)$, forming four groups. The lowest FW hybrids that did not differ statistically were the UENF/Caliman $01(1049.75 \mathrm{~g}), \mathrm{CP} 3 \times$ SSAM $(894.52 \mathrm{~g}), \mathrm{CP} 3 \times \mathrm{UENF} / \mathrm{Caliman} 01(1049.41 \mathrm{~g})$ and JS $12 \times \mathrm{SSAM}(1045.64 \mathrm{~g})$. The hybrids yielding the highest fruit weight consisted of CP3 $\times$ JS12 $(1921.64 \mathrm{~g})$, CP1 $\times$ Sekati $(1731.56 \mathrm{~g})$ and CP1 $\times$ JS12 $(1865.90 \mathrm{~g})$, which showed the lowest values for TMF as a compensatory effect $(<\mathrm{TMF}>\mathrm{FW})$.

According to Dias et al. (2011), fruits with average weight between 800 and $1500 \mathrm{~g}$ serve the national market, while the external market still requires weight around $500 \mathrm{~g}$. Alonso et al. (2009), evaluating papaya hybrids in Cuba obtained average weight with low variability ranging from 1456.7 to $1682.4 \mathrm{~g}$. These results highlight the commercialization potential of these hybrids in the national market.

The cultivars of the "Formosa" group show larger fruits and they are usually commercial hybrids, which has conquered the internal and external markets, mainly Europe, Canada and the United States (Dantas \& Oliveira, 2009). The acquisition of new genotypes of the Formosa group with commercial characteristics demanded by the market has been a considerable demand worldwide (Esquivel et al., 2008).

For the FL and FD characteristics, the averages ranged from 17.88 to $28.74 \mathrm{~cm}$ and 9.97 to $12.33 \mathrm{~cm}$, respectively. Rodolfo Jr. et al. (2007) making the physical and chemical characterization of fruits from the "Formosa" cultivars, observed that the length of the fruits reached the average of $25.60 \mathrm{~cm}$. In this work, the FL characteristic formed four different groups, indicating that there was significant variability when comparing the hybrids. For the FD characteristic three distinct groups were formed.

In the study of 59 accessions of the active Papaya germplasm bank, Silva et al. (2017) also observed great variability in fruit size, the American access of the "Formosa" group presented the highest fruit length $(39.00 \mathrm{~cm})$ and the STZ 03 Petiole-short access from the "Solo" group presented $(11.00 \mathrm{~cm})$ for this characteristic.

For the FL/FD ratio two groups were formed, and the group of higher averages was represented by five hybrids including the control, with averages varying from 2.11 to 2.42 . The ratio (FL/FD) may indicate a standard format that is required in the papaya trade. The variation in the physical characteristics of the fruits is related to factors such as edaphoclimatic conditions, cultural practices, cultivar, planting season, harvesting and postharvest handling (Fagundes \& Yamanishi, 2001).

The GFT and the MFT of the pulp ranged from 2.76 to 3.65 and 2.04 to $2.65 \mathrm{~cm}$ among the evaluated hybrids, presenting average values close to $2.00 \mathrm{~cm}$, considered ideal value for commercialization (Martins et al., 2006). Oliveira et al. (2010) observed a significant and positive correlation, although of low magnitude (0.42), between pulp thickness and fruit firmness.

The FCD characteristic presented two groups, being the lowest value obtained for the hybrid CP3 $\times$ UENF/Caliman $01(5.24 \mathrm{~cm})$. According to Fioravanço, Paiva, Carvalho, and Manica (1992), and Dias et al. 
(2011), FCD is related to fruit quality, since those with lower value generally have a greater amount of pulp and are more resistant when transported to more distant markets.

The eight-month SS (SS-8) ranged from 9.34 to $12.61^{\circ}$ Brix and formed three distinct groups, the hybrids that make up the highest average group are the UENF/Caliman 01 (12.13 $\left.{ }^{\circ} \mathrm{Brix}\right) \mathrm{CP} 3 \times \mathrm{SSAM}\left(12.27^{\circ} \mathrm{Brix}\right)$ and $\mathrm{JS} 12 \times \operatorname{SSAM}\left(12.61{ }^{\circ} \mathrm{Brix}\right)$. In the 12-month evaluation (SS-12) the values ranged from 11.25 to $14.50{ }^{\circ} \mathrm{Brix}$, forming 2 groups where 3 hybrids make up the highest average group being the UENF/Caliman 01 (14.50 $\left.{ }^{\circ} \mathrm{Brix}\right)$, JS12 $\times$ SSAM (13.50 ${ }^{\circ}$ Brix) and CP1 $\times$ Progeny Tainung (13.50 ${ }^{\circ}$ Brix). Marin et al. (2006a) when analyzing papaya hybrids obtained between the 'Solo' and 'Formosa' groups, observed values between 7.85 and $12.65^{\circ}$ Brix.

Oliveira et al. (2010), evaluating 19 accessions of the active germplasm bank, two varieties of the "Solo" group and the UENF/Caliman 01 hybrid observed values of SS between 5.00 and $16.20^{\circ}$ Brix. However, values of 10.24 to $12.27^{\circ}$ Brix were observed by Silva et al. (2008) in the analysis of segregating populations. The results found in this work are consistent with the requirements of the fruit market of the "Solo" group, which is of the order of $11.5^{\circ}$ Brix (Fagundes \& Yamanishi, 2001). Martins et al. (2006) and Grizotto, Berbari, Moura and Claus (2006), observed that SS values should be 11.5 to $11.6^{\circ} \mathrm{Brix}$ in the fruit pulp, being this dependent on the maturation stage at which the fruit is harvested (M. I. F. Chitarra \& A. B. Chitarra, 2005). These differences may be related to fluctuations in the source-drain relationship, which occurs throughout the cycle, which we know can affect sugar levels in papaya (Zhou, Chistopher, \& Paull, 2000).

The FIRM value was evaluated at eight (FIRM-8) and at 12 months (FIRM-12) and ranged from 8.49 to 12.18 and 8.00 to $12.50 \mathrm{kgf} \mathrm{cm}^{-2}$, respectively. For the FIRM- 8 characteristic two groups were formed and the group with the lowest values was represented by the hybrid CP3 $\times \operatorname{SSAM}\left(8.49 \mathrm{kgf} \mathrm{cm}^{-2}\right)$, the other 10 hybrids that make up the group of higher averages presented values oscillating from 10.30 to $12.18 \mathrm{~cm}^{-2}$. For the FIRM-12 characteristic, two groups were formed, among the group of smaller means we have the hybrids CP3 $\times$ SSAM $\left(8.00 \mathrm{kgf} \mathrm{cm}^{-2}\right), \mathrm{CP} 1 \times \operatorname{Sekati}\left(8.75 \mathrm{kgf} \mathrm{cm}^{-2}\right), \mathrm{CP} 2 \times \operatorname{SS} 32\left(8.75 \mathrm{kgf} \mathrm{cm}^{-2}\right)$, JS $12 \times \operatorname{SSAM}\left(9.67 \mathrm{kgf} \mathrm{cm}^{-2}\right)$ and the control UENF/Caliman $01\left(10.50 \mathrm{kgf} \mathrm{cm}^{-2}\right)$, the remaining six hybrids that make up the higher values presented values ranging from 11.50 to $12.50 \mathrm{kgf} \mathrm{cm}^{-2}$.

Viana, Reis, Silva, Neves, and Jesus (2015), in a physical-chemical and sensory evaluation of fruits of improved papaya genotypes obtained a maximum firmness value of $8.35 \mathrm{kgf} \mathrm{cm}^{-2}$, lower value than those found in the genotypes evaluated in this experiment, indicating consistent values for the FIRM characteristic.

The fruits with low firmness present less resistance to transportation, storage and handling (Fagundes \& Yamanishi, 2001; Morais, Silva, Menezes, Maia, \& Junior, 2007). Demand that greater recommendations be made regarding the transportation and commercialization of the fruits that present less firmness of the pulp.

The PROD characteristic ranged from 105.08 to 162.74 ton $\mathrm{ha}^{-1}$, forming two groups, the largest group consisting of four hybrids, CP3 $\times 72 / 12\left(162.74\right.$ ton $\left.^{-1} \mathrm{f}^{-1}\right), \mathrm{CP} 2 \times \mathrm{SS} 32\left(152.36\right.$ ton $\left.^{-1} \mathrm{a}^{-1}\right), \mathrm{CP} 3 \times$ Tainung Progeny $\left(151.09 \text { ton }^{-1}\right)^{2}$ and CP1 $\times$ JS 12 (141.92 ton $\left.\mathrm{ha}^{-1}\right)$. The other seven hybrids make up the group "b" of lower averages that ranged from 105.08 ton $\mathrm{ha}^{-1}$ to 127.50 ton $\mathrm{ha}^{-1}$. The PROD of the 11 hybrids under evaluation was very satisfactory when compared to other hybrids of the Formosa group commercially exploited with averages ranging from 80 to 106 tons ha $^{-1}$ (Feitosa, Araujo, Oliveira, Lopes, \& Andrade, 2016) and experimentally as the Tainung 01 hybrid in response to irrigation and soil cover showed yields of 138.1 to 175.7 tons ha ${ }^{-1}$, in which each plant produced, on average, 55.6 fruits throughout the cycle (Gomes Filho, Oliveira, Viana, \& Pereira, 2008).

According to Marin, Yamanishi, Marteleto, and Ide (2003) the preference is for hermaphrodite papaya plants with a peripheral and/or elongated shape, which is associated with a smaller ovarian cavity and a greater thickness of the pulp. This characteristic gives a greater commercial value to the fruit in the market. Compatible characteristics can be seen in Figures 1 and 2. 


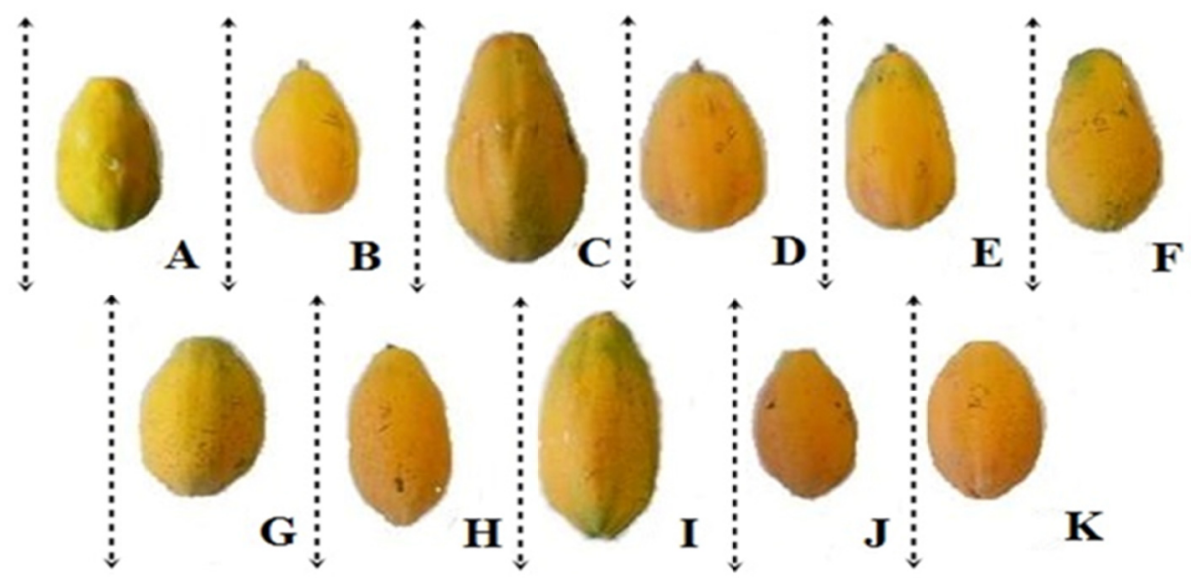

Figure 1. Fruits representation of the $3 / 4$ maturation stage of the 11 papaya hybrids (Carica papaya L.)

Note. A: CP3 $\times$ SSAM; B: CP3 $\times$ UENF/Caliman 01; C: CP3 $\times$ JS 12; D: CP3 $\times 72 / 12$; E: CP3 $\times$ Tainung Progeny; F: CP1 $\times$ Sekati; G: CP1 $\times$ Tainung Progeny; H: CP1 $\times$ JS 12; I: CP2 $\times$ SS32; J: JS $12 \times$ SSAM; K: UENF/Caliman 01.

* The dotted arrow to the left of each fruit represents $40 \mathrm{~cm}$ in length.

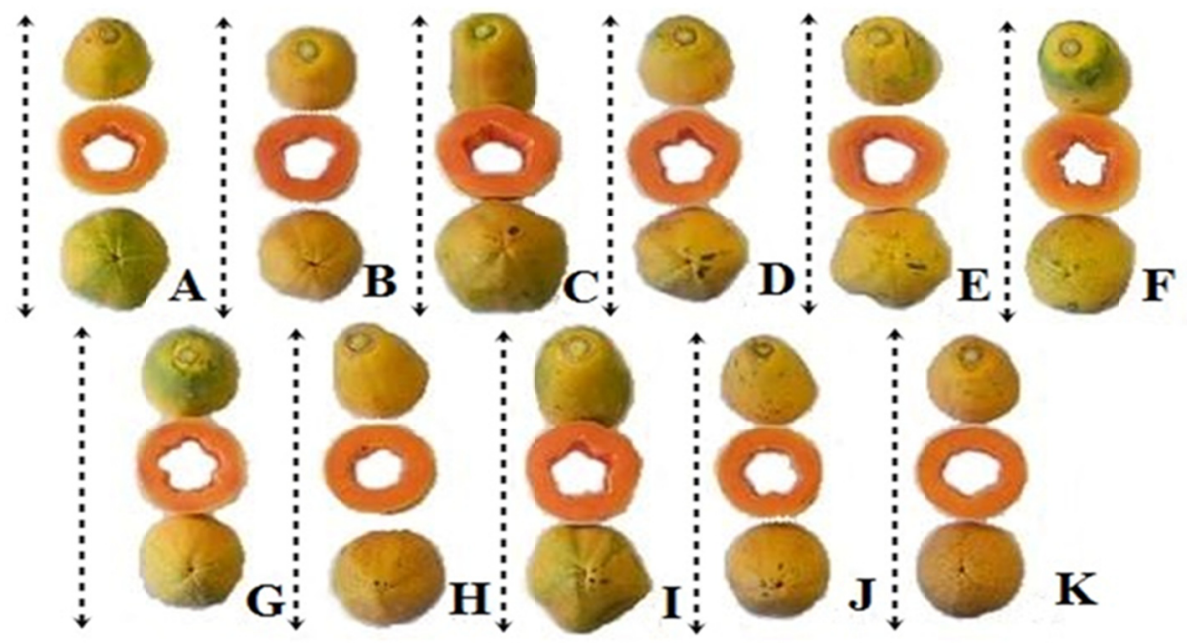

Figure 2. Fruits representation, in cut, of the $3 / 4$ maturation stage of the 11 papaya hybrids (Carica papaya L.)

Note. A: CP3 $\times$ SSAM; B: CP3 $\times$ UENF/Caliman 01; C: CP3 $\times$ JS 12; D: CP3 $\times 72 / 12$; E: CP3 $\times$ Tainung Progeny; F: CP1 $\times$ Sekati; G: CP1 $\times$ Tainung Progeny; H: CP1 $\times$ JS 12; I: CP2 $\times$ SS32; J: JS $12 \times$ SSAM; K: UENF/Caliman 01.

* The dotted arrow to the left of each fruit represents $40 \mathrm{~cm}$ in length. The shape of the ovarian cavity dependents on the carpel formation.

According to Ruggiero (1988), a small interior cavity is preferred, in which it provides a greater amount of pulp with seeds that are easy to remove. The pulp of the hybrids under study presented the orange coloration indicating possibly a good acceptance of the consumers (Figure 2). The coloration of the pulp is an aspect that determines the acceptance by the consumer, because they present the preference for fruits of dark orange pulp (Miranda et al., 2002). In some cases, the coloring of the pulp may be reddish depending on the climatic conditions, especially the solar radiation.

The hybrids studied present phenotypic characteristics acceptable to the consumer market of papaya fruits worldwide and nationally. In view of the results we can explore the hybrids of papaya as options with potential to satisfy the demand of consumers and producers of papaya. 
In general, based on the results found, it can be stated that the hybrids studied showed good adaptation to the culture conditions. This represents a major advance for the development of future breeding programs for papaya and its use for national and international marketing with phenotypic characteristics introduced acceptable to the fruit consumption market.

\section{Conclusions}

Among the new hybrids evaluated, the presence of productive characteristics and fruit quality were interesting for the market, suggesting that they be evaluated for crop value and use for future commercial hybrids.

With interest for future market launch, we highlight CP3 $\times 72 / 12, \mathrm{CP} 2 \times \mathrm{SS} 32, \mathrm{CP} 3 \times$ Progeny Tainung and CP1 $\times$ Sekati that present high average productivity of marketable fruits in 12 months.

\section{References}

Alonso, M., Tornet, Y., Ramos, R., Farrés, E., \& Rodríguez, D. (2009). Evaluación de dos híbridos de papaya introducidos en Cuba. Agronomía Costarricense, 33(2), 267-274.

Alonso, M., Tornet, Y., Ramos, R., Farrés, EP., Castro, J., \& Rodríguez, M. C. (2008). Evaluación de tres cultivares de papaya del Grupo Solo basada em caracteres de crecimiento y productividad. Cultivos Tropicales, 29(2), 59-64.

Aroucha, E. M. M., Silva, R. F., Oliveira, J. G., Viana, A. P., \& Pereira, M. G. (2009). Época de colheita e período de repouso de frutos de mamão (Carica papaya L.) cv. Golden na qualidade fisiológica das sementes. Ciência Rural, 35(3), 537-543. https://doi.org/10.1590/S0103-84782005000300008

Chitarra, M. I. F., \& Chitarra, A. B. (2005). Pós-colheita de frutos e hortaliças: fisiologia e manuseio. Lavras: Fundação de Apoio ao Ensino, Pesquisa e Extensão.

Costa, A. N., \& Costa, A. F. S. (2013). Ferreguetti, G. A. Manejo da fertilidade do solo e da nutrição do mamoeiro. Informe Agropecuário, 34, 38-47.

Cruz, C. D. (2016). Genes Software-Extended and integrated with the R, Matlab and Selegen. Acta Scientiarum Agronomy, 38(4), 547-552. https://doi.org/10.4025/actasciagron.v38i4.32629

Dantas, J. L. L., \& Oliveira, E. J. (2009). O melhoramento genético do mamoeiro: Avanços, desafios e perspectivas (pp. 151-180). Simpósio Nordestino de Genética e Melhoramento de Plantas. Anais... Fortaleza: Embrapa Agroindústria Tropical.

Dantas, L. J. L., \& Lima, J. F. (2001). Seleção e recomendação de variedades de mamoeiro-avaliação de linhagens e híbridos. Revista Brasileira de Fruticultura, 23(3), 617-621. https://doi.org/10.1590/S010029452001000300035

Dias, N. L. P., Oliveira, E. J., \& Dantas, J. L. L. (2011). Avaliação de genótipos de mamoeiro com uso de descritores agronômicos e estimação de parâmetros genéticos. Pesquisa Agropecuária Brasileira, 46(11), 1471-1479. https://doi.org/10.1590/S0100-204X2011001100008

Esquivel, M. A., Quintana, Y. T., Ramírez, R. R., Armenteros, E. F., González, M. A., \& Martínez, D. R. (2008). Caracterización y evaluación de dos híbridos de papaya en cuba. Agricultura Técnica en México, 34(3), 333-339.

Fagundes, G. R., \& Yamanishi, O. K. (2001). Características físicas e químicas de frutos de mamoeiro do grupo 'Solo' comercializados em quatro estabelecimentos de Brasília-DF. Revista Brasileira de Fruticultura, 23(3), 541-545. https://doi.org/10.1590/S0100-29452001000300018

Feitosa, E. O., Araújo, A. F. B., Oliveira, C. M. B., Lopes, F. B., \& Andradre, E. M. (2016). Irrigation productivity and water-use efficiency in papaya crop under semi-arid conditions. African Journal of Agricultural Research, 11(42), 4181-4188. https://doi.org/10.5897/AJAR2016.11650

Ferreira, J. P., Schmildt, E. R., Schmildt, O., Cattaneo, L. F., Alexandre, R. S., \& Cruz, C. D. (2016). Comparison of methods for classification of the coefficient of variation in papaya. Revista Ceres, 63(2), 138-144. https://doi.org/10.1590/0034-737X201663020004

Fioravanço, J. C., Paiva, M. C., Carvalho, R. I. N., \& Manica, I. (1992). Qualidade do mamão solo comercializado em Porto Alegre de outubro/91 a junho/92. Revista Ciência Agronômica, 23(3), 1-5.

Fraife Filho, G. A., Dantas, J. L. L., Leite, J. B. V., \& Oliveira, J. R. P. (2001). Avaliação de variedades de mamoeiro no extremo sul da Bahia. Magistra, 13, 37-41. 
Gomes Filho, A., Oliveira, J. G., Viana, A. P., \& Pereira, M. G. (2008). Mancha fisiológica e produtividade do mamão Tainung 01: Efeito da lâmina de irrigação e cobertura do solo. Ciência e Agrotecnologia, 32(4), 1161-1167. https://doi.org/10.1590/S1413-70542008000400019

Grizotto, R., Berbari, S. A. G., Moura, S. C. S. R., \& Claus, M. L. (2006). Estudo da vida-de-prateleira de fruta estruturada obtida de polpa concentrada de mamão. Ciência e Tecnologia de Alimentos, 11, 709-714. https://doi.org/ 10.1590/S0101-20612006000300035

IBGE (Instituto Brasileiro de Geografia e Estatística). (2015). Banco de dados agregados: culturas permanentes: mamão. Grupo de Coordenação de Estatísticas Agropecuárias-GCEA/IBGE; Diretoria de Pesquisas, Coordenação de Agropecuária, Levantamento Sistemático da Produção Agrícola-LSPA. Retrieved from https://sidra.ibge.gov.br/tabela/5457\#resultado

Ide, C. D., Pereira, M. G., Viana, A. P., \& Pereira, T. N. S. (2009). Use of testes for combining ability and selection of papaya hybrids. Crop Breeding and Applied Biotecnology, 9, 60-66. https://doi.org/10.12702/ 1984-7033.v09n01a09

Luz, L. N., Pereira, M. G., Barros, F. R., Barros, G. B., \& Ferreguetti, G. A. (2015). Novos híbridos de mamoeiro avaliados nas condições de cultivo tradicional e no semiárido brasileiro. Revista Brasileira de Fruticultura, 37(1), 159-171. https://doi.org/10.1590/0100-2945-069/14

Marin, L. S. D., Yamanishi, K. O., Martelleto, L. A., \& Ide, C. D. (2003). Hibridação de mamão. In D. S. Martins, (Ed.). Papaya Brasil: qualidade do mamão para mercado interno (pp. 173-188). Vitoria, ES: Incaper.

Marin, S. L. D., Pereira, M. G., Amaral Júnior, A. T., Martelleto, L. A. P., \& Ide, C. D. (2006a). Heterosis in papaya hybrids from partial diallel of 'Solo' and 'Formosa' parents. Crop Breeding and Applied Biotechnology, 6, 24-29. https://doi.org/10.12702/1984-7033.v06n01a04

Marin, S. L. D., Pereira, M. G., Amaral Júnior, A. T., Martelleto, L. A. P., \& Ide, C. D. (2006b). Partial diallel to evaluated the combinig ability for economically important traits of papaya. Scientia Agricola, 63(6), 540-546. https://doi.org/10.1590/S0103-90162006000600005

Martins, G. N., Silva, R. F., Pereira, M. G., Araújo, E. F., \& Posse, S. C. P. (2006). Influência do repouso pós-colheita de frutos na qualidade fisiológica de sementes de mamão. Revista Brasileira de Sementes, 28(2), 142-146. https://doi.org/10.1590/S0101-31222006000200019

Miranda, S. P., Fagundes, G. R., Machado Filho, J. A., Moraes, A. V., Lima, L. A., \& Yamanishi, O. K. (2002). Caracterização física e química de mamões dos grupos solo e formosa cultivados em Brasília-DF. XVII Congresso Brasileiro de Fruticultura, 17. Anais... Belém: Sociedade Brasileira de Fruticultura.

Morais, P. L. D., Silva, G. G., Menezes, J. B., Maia, F. E. N., \& Junior, R. S. (2007). Pós-colheita de mamão híbrido UENF/Caliman 01cultivado no Rio Grande do Norte. Revista Brasileira de Fruticultura, 29(3), 666-670. https://doi.org/10.1590/S0100-29452007000300046

Nakasone, H. Y., \& Lamoureux, C. (1982). Transitional forms of hermaphroditic papaya flowers leading to complete maleness. Journal of the American Society for Horticultural Science, 107, 589-592.

Oliveira, E. J., Lima, D. S., Lucena, R. S., Motta, T. B. N., \& Dantas, J. L. L. (2010). Correlações genéticas e análise de trilha para número de frutos comerciais por planta em mamoeiro. Pesquisa Agropecuária Brasileira, 45(8), 855-862. https://doi.org/10.1590/S0100-204X2010000800011

Paixão, M. V. S., Schmildt, E. R., Mattiello, H. N., Ferreguetti, G. A., \& Alexandre, R. S. (2012). Frações orgânicas e mineral da produção de mudas de mamoeiro. Revista Brasileira de Fruticultura, 34(4), 1105-1112. https://doi.org/10.1590/S0100-29452012000400018

Rodolfo Júnior, F., Torres, L. B. V., Campos, V. B., Lima, A. R., Oliveira, A. D., \& Mota, J. K. M. (2007). Caracterização físico-química de frutos de mamoeiro comercializados na Empasa de Campina Grande-PB. Revista Brasileira de Produtos Agroindustriais, 9(1), 53-58. https://doi.org/10.15871/1517-8595/rbpa. v9n1p53-58

Rodríguez, M. C., \& Rosell, P. (2005). Productividad y características fenológicas de los cultivares de papaya Sunrise y Baixinho de Santa Amalia en invernadero de malla en la zona suroeste de la isla de Tenerife. Actas Portuguesas de Horticultura, 6, 245-249.

Ruggiero, C. (1988). Situação da cultura do mamoeiro no Brasil (pp. 5-18). Simpósio Brasileiro Sobre a Cultura do Mamoeiro, 2. Anais... Jaboticabal: FCAV/UNESP. 
Scott, A. J., \& Knott, M. A. (1974). Clusters analysis method for grouping means in the analysis of variance. Biometrics, 30(3), 507-512. https://doi.org/10.2307/2529204

Silva, C. A., Nascimento, A. L., Ferreira, J. P., Schmildt, O., Malikouski, R. G., Alexandre, R. S., ... Schmildt, E. R. (2017). Genetic diversity among papaya accessions. African Journal of Agricultural Research, 12(23), 2041-2048. https://doi.org/10.5897/AJAR2017.12387

Silva, F. F., Pereira, M. G., Ramos, H. C. C., Damasceno Junior, P. C., Pereira, T. N. S., \& Ide, C. D. (2007). Genotypic correlations of morpho-agronomic traits in papaya and implications for genetic breeding. Crop Breeding and Applied Biotechnology, 7, 345-352. https://doi.org/ 10.12702/1984-7033.v07n04a03

Silva, F. F., Pereira, M. G., Ramos, H. C., Damasceno Junior, P. C., Pereira, T. N. S., Viana, A. P., ... Ferreguetti, G. A. (2008). Estimation of genetic parameters related to morpho-agronomic and fruit quality traits of papaya. Crop Breeding and Applied Biotechnology, 8, 65-73. https://doi.org/10.12702/1984-7033. v08n01a09

Viana, E. S., Reis, R. C., Silva, S. C. S., Neves, T. T., \& Jesus, J. L. (2015). Avaliação físico-química sensorial de frutos de genótipos melhorados de mamoeiro. Pesquisa Agropecuária Tropical, 45, 297-303. https://doi.org/ $10.1590 / 1983-40632015 \mathrm{v} 4535008$

Zhou, L., Chistopher, D., \& Paull, R. (2000). Defoliation and fruit removal effects on papaya fruit production, sugar metabolism, and sucrose metabolism. Journal of the American Society for Horticultural Science, $125(5), 644-652$.

\section{Copyrights}

Copyright for this article is retained by the author(s), with first publication rights granted to the journal.

This is an open-access article distributed under the terms and conditions of the Creative Commons Attribution license (http://creativecommons.org/licenses/by/4.0/). 